\title{
Anatomic Stage I Breast Cancer AJCC v8
}

National Cancer Institute

\section{Source}

National Cancer Institute. Anatomic Stage I Breast Cancer A/CC v8. NCI Thesaurus. Code C139535.

Stage I includes: IA: (T1, N0, M0); IB: (T0, N1 mi, M0); (T1, N1 mi, M0). T0: No evidence of primary tumor. T1: Tumor measuring $20 \mathrm{~mm}$ or less in greatest dimension. N0: No regional lymph node metastasis is identified or isolated tumor cell clusters (ITCS) are identified only. N1 mi: Tumor with micrometastases (approximately 200 cells, larger than $0.2 \mathrm{~mm}$, but none larger than $2.0 \mathrm{~mm}$ ). M0: No clinical or radiographic evidence of distant metastases. Imaging studies are not required to assign the M0 category. (AJCC 8th ed.) 